
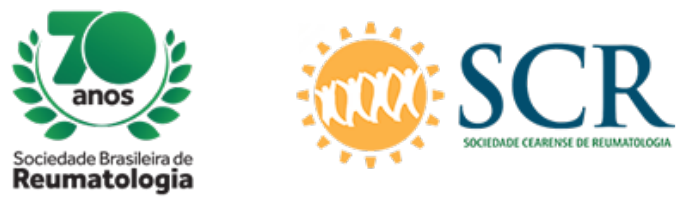

\title{
EFFECTS OF THE PILATES METHOD ON CHRONIC LUMBAR PAIN DOES NOT SPECIFIC: A SYSTEMATIC REVIEW STUDY
}

Francisco Dimitre Rodrigo Pereira Santos (UNIDADE DE ENSINO SUPERIOR DO SUL DO MARANHÃO, Imperatriz, MA, Brasil), Marciene Sousa Cavalcante Costa (UNIDADE DE ENSINO SUPERIOR DO SUL DO MARANHÃO, Imperatriz, MA, Brasil), Hellyangela Bertalha Blascovich (UNIDADE DE ENSINO SUPERIOR DO SUL DO MARANHÃO, Imperatriz, MA, Brasil), Letícia Bezerra Brito (UNIDADE DE ENSINO SUPERIOR DO SUL DO MARANHÃO, Imperatriz, MA, Brasil), Leonardo Boni Souza da Silva (UNIDADE DE ENSINO SUPERIOR DO SUL DO MARANHÃO, Imperatriz, MA, Brasil), Aparecida Amparo Barros de Deus (UNIDADE DE ENSINO SUPERIOR DO SUL DO MARANHÃO, Imperatriz, MA, Brasil), Priscila Kellen Nascimento Roza (UNIDADE DE ENSINO SUPERIOR DO SUL DO MARANHÃO, Imperatriz, MA, Brasil), Raisa Ramos dos Anjos (UNIDADE DE ENSINO SUPERIOR DO SUL DO MARANHÃO, Imperatriz, MA, Brasil), Rosana Matos da Silva (UNIDADE DE ENSINO SUPERIOR DO SUL DO MARANHÃO, Imperatriz, MA, Brasil), Ruan Pablo Lima da Silva (UNIDADE DE ENSINO SUPERIOR DO SUL DO MARANHÃO, Imperatriz, MA, Brasil), Andressa Braga de Araújo (UNIDADE DE ENSINO SUPERIOR DO SUL DO MARANHÃO, Imperatriz, MA, Brasil), Waueverton Bruno Wyllian Nascimento Silva (UNIDADE DE ENSINO SUPERIOR DO SUL DO MARANHÃO, Imperatriz, MA, Brasil), Thyago Duarte Silva (UNIDADE DE ENSINO SUPERIOR DO SUL DO MARANHÃO, Imperatriz, MA, Brasil), Eronilde Silva Gonçalves (UNIDADE

DE ENSINO SUPERIOR DO SUL DO MARANHÃO, Imperatriz, MA, Brasil), Fernanda Carneiro Ramos

(UNIDADE DE ENSINO SUPERIOR DO SUL DO MARANHÃO, Imperatriz, MA, Brasil), Arthur Barros Fernandes (UNIVERSIDADE FEDERAL DO MARANHÃO, Imperatriz, MA, Brasil)

\section{BACKGROUND}

The Pilates method presents significant results in the treatment of chronic nonspecific low back pain, evidencing that the exercises based on muscle activation, strengthening and stretching reduce pain intensity, which in turn influences the improvement of clinical condition. The aim of the study was to verify the effects of the Pilates method on patients with chronic nonspecific low back pain.

\section{MATERIALS AND METHODS}

Systematic Review Study (PROSPERO-CRD42017072358); in electronic databases MEDLINE, PEDro, SciELO and LILACS. The terms for the searches were in accordance with the strategies established by the Cochrane Back Review Group; the searches were adjusted to each of the bases. The research was carried out between the months of june and july of 2018, with the inclusion of randomized clinical trials, with adults, of both sexes, with chronic non-specific back pain; studies in which the main treatment was based on the Pilates method compared with no intervention, or minimal intervention, or other types of interventions, or exercises; studies published in scientific journals between 2013 and 2018 and without language restriction. To analyze the studies were collected the data related to the type of study, allocation of the groups and the evaluation tools used; data on participants, intervention, duration and frequency of treatment, results and conclusion. The process of selecting the articles included in the analysis was according to the flowchart PRISMA. To evaluate the methodological quality of the studies, the quality scale was used PEDro.

\section{RESULTS}

Among the 350 found, eight articles included for full reading, of these three were excluded, resulting in five studies. Two of the articles compared the Pilates method with another intervention and three with no intervention; the findings showed that the Pilates method presents a reduction of non-specific chronic low back pain, as well as the other interventions performed. However, one of the studies pointed out that segmental stabilization is more effective in at reducing pain and activation of the stabilizing muscles of 
the lumbar spine when compared to the Pilates method. When referring to the quality of life the studies indicate that the Pilates method presents more significant results. Regarding functional capacity, the Pilates method presented significant results in all studies.

\section{CONCLUSION}

All the interventions were positive, however the Pilates method showed more significant results in pain reduction, functional capacity and quality of life; the segmental stabilization is more affective at muscle activation and pain in some studies. 